\section{About what is happening in the stomach after swallowing human river pebbles, gravel, chalk, clay and tablets drugs}

\begin{abstract}
ALEKSANDR URAKOV - Izhevsk State Medical Academy - urakoval@live.ru
NATALIA URAKOVA - Izhevsk State Medical Academy - urakovanatal@male.ru

ALEXEY RESHETNIKOV - Izhevsk State Medical Academy • areshetnikov@list.ru

ANTON KASATKIN - Institute of Thermology - ant-kasatkin@yandeks.ru

MAXIM KOPYLOV - Izhevsk State Medical Academy - kopilov@inbox.ru

DMITRY BAIMURZIN - Izhevsk State Medical Academy • nevi_dimko@male.ru
\end{abstract}

Érkezett: 2016. 10. 23. - Received: 23. 10. 2016. - http://dx.doi.org/10.14382/epitoanyag-jsbcm.2016.19

\section{Abstract}

It was found that pharmaceutical companies produce drugs in tablet form, physical or physical-chemical properties that are radically different from those of the properties of natural food lumps, in that adults convert food in the mouth before swallowing. It was shown that the conventional shape, color, size, volume, specific gravity, hardness, osmotic and acid activity of modern tablets impair the physical and physicochemical properties of the liquid content of the stomach is much stronger than such building materials, such as chalk, clay, sand, river pebbles and gravel.

Keywords: human, pills, drugs, clay, chalk, gravel, pebbles, physical-chemical properties
Aleksandr L. URAKOV, MD Head of Department of General and Clinical Pharmacology Izhevsk State Medical Academy (since 1988) in lzhevsk, Russia. Since then 36 doctors and biologists from the department have successfully defended dissertations (PhD) under the supervision Prof. Urakov. He is author or coauthor 170 patents, 15 books and more than 300 scientific papers.

Natalia A. URAKOVA, Assistant of the Department of Obstetrics and Gynecology of Izhevsk State Medical Academy, Russia, PhD in Medical Science 2005. Scientific interests: obstetrics and gynecology, physical and chemical pharmacology, infrared thermography, hypoxia, new materials in medicine.

Aleksei P. RESHETNIKOV Director of the Dental Clinic "ReSto", Russia, PhD in Medical Science 2010. Scientific interests: dentistry, physical and chemical pharmacology, infrared thermography, new materials in medicine

Anton A. KASATKIN Assistant of the Department of General and Clinical Pharmacology of Izhevsk State Medical Academy, Russia, PhD in Medical Science 2010. Scientific interests: physical and chemical pharmacology, infrared thermography, new materials in medicine.

Maxim V. KOPYLOV

Aspirant of the Department of General and Clinical Pharmacology of Izhevsk State Medical Academy, Russia, Scientific interests: stomatology, physical and chemical pharmacology, infrared thermography, new materials in medicine. advertised forms of medications. Powerful advertising of tabletform medications made people directly associate medications with tablets [1]. Therefore, today most people think of medications as tablets, and that is why tablets are in greater demand by consumers than injectable ampoules, ointment tubes, and capsules with powder (Fig. 1). In Hungary, it is pills that enjoy the best sales among other forms of medications.

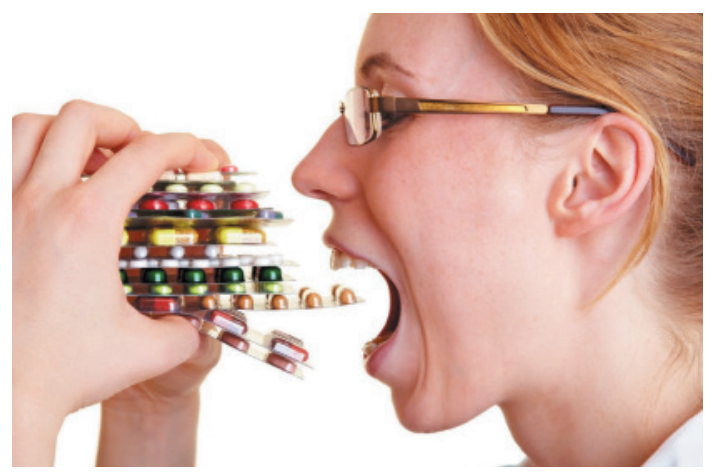

Fig. 1. The amount of production was the largest with tablets, which made up 52.1\%, followed by capsules (5.6\%), injectable solutions (5.6\%), and powders and granules, etc. (5.4\%). These four categories made up $68.7 \%$ of total. (http://www.mhlw.go.jp/topics/yakuji/2011/nenpo/dl/insathu_e.pdf)

1. ábra A legnagyobb mennyiségben tablettákat gyártanak (52,1\%), ezt követik a kapszulák (5,6\%), injekciós oldatok (5,6\%), porok, granulátumok és egyebek $(5,4 \%)$. Ez a négy kategória a teljes mennyiség 68,7\%-át teszi ki. (http://www.mhlw.go.jp/topics/yakuji/2011/nenpo/dl/insathu_e.pdf)

Let us consider tablets in the framework of competitive materials and technology processes. Surprisingly, modern tablets are manufactured by compressing powders, as they were a hundred years ago [2]. Therefore, they are hard and resemble
Dmitry BAIMURZIN

Aspirant of the Department of General and Clinical Pharmacology of Izhevsk State Medical Academy, Russia, Scientific interests: stomatology, physical and chemical pharmacology, infrared thermography, new materials in medicine.

natural stones. Typically, these artificially made stones look like white or gray circular shaped disks. Before we studied physical and chemical properties of more than 50 tablets and found that physical and chemical properties and aggregate state of modern tablets are very similar to comparable pieces of chalk, clay and/ or compressed salt. Therefore, all modern tablets are harder than high quality food, so they sink in gastric juice $[4,5,6]$.

However, a man is not a bird whose stomach is tailored for stones to grind down solid food (Fig. 2).
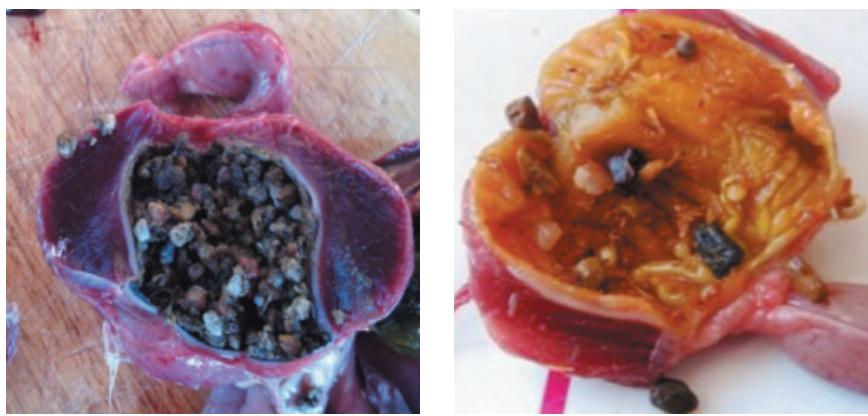

Fig. 2 A general view of the contents of the stomachs of domestic hens (1 and 2) after opening the stomach

2. ábra Házi tyúk gyomrának tartalma a gyomor felnyitását követöen 
Human body is not capable to swallow natural and artificial stones. That is why human stomach is not adapted for stones of any size and shape, including silica sand, crushed stone and river pebbles. Similarly, human stomach is not adapted for medical stones, or tablets (Fig. 3).

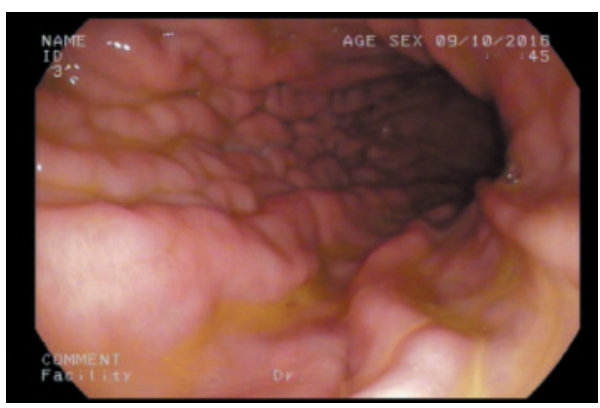

Fig. 3. The image of the stomach mucosa of a living person (man, age 48 years), obtained from the inside using endovideoscopy

3. ábra Élö személy gyomorfalának képe endovideoszkópiás felvételen (48 éves férfi)

It is paradoxical, but true. Our results have shown that silica sand, river pebbles and crushed stones have less damaging impact on the human stomach than modern tablet-form medications $[3,7]$. A person can stay healthy after swallowing a tablet-size grain of sand, pebbles and crushed stones. However, a man will not stay healthy after swallowing comparable number of most modern tablets $[8,9,10]$.

Nevertheless that this fact still does not scare humankind. It seems like people are hypnotized and do not realize that tabletform medications are much more aggressive than natural stones and food $[11,12]$. People do not want to see that tabletform medications are as hard as rocks, so when a person chew the tablets, he may break his jaw, prosthesis, tooth, crowns, implants, braces or fillings and injure his gums, tongue and palate. When swallowing the tablets without chewing, one can damage his esophagus and stomach, and even get ulcers [3, 13].

Our results show that tablets quality standard does not consider their hardness. Therefore, every manufacturer has the right to make tablets of any hardness, moreover, he is entitled not to define it or inform the consumer about it. Worse yet, today, the drugs manufacturers do not control the osmotic and acidic impact of tablets and their local irritant effect on the mucous membranes of the mouth and stomach. However, all of them manufacture tablets with extremely high hyperosmotic and acid activity, as if they operate in collusion with each other.

Therefore, almost all modern tablets demonstrate high physical and chemical aggressiveness and therefore have acute local irritant and burning effects. All this contributes to the development of drug-caused iatrogenesis, such as gingivitis, stomatitis, gastritis, gastric ulcers and tooth decay [3]. Many of these adverse consequences caused by taking tablets are easily detected with a thermal imaging camera by defining local hyperthermia area.

\section{Materials and methods}

In the laboratory settings, we studied physical and physicalchemical properties of more than 50 tablets of various medications produced by different pharmaceutical companies worldwide. We analyzed their shape, color, weight, diameter, height, volume, acidity and osmolarity. Conventional methods and equipment for drugs quality control were used for this purpose. Additionally, we measured the tablets hardness by Rockwell hardness test method. We also measured hardness at specific load in Brinell scale (in HB units).

At the same time, we monitored the dynamics of food and tablets movement inside the body, and analyzed viscosity, temperature, acidity and osmolarity of gastric contents. The studies were conducted using a plastic model of the stomach. For this purpose, we used a clear, colorless $1000 \mathrm{ml}$ plastic container. To imitate food, we introduced $180 \mathrm{~g}$ of oatmeal, and $150 \mathrm{ml}$ of milk and/or water into the container. After putting food and tablets, we added $150 \mathrm{ml}$ of natural gastric juice with $\mathrm{pH}$ 0.8-1.2. All substances were introduced into the vessel at a temperature of $+37^{\circ} \mathrm{C}$. In a parallel series of experiments in the stomach cavity of the input pieces of chalk, clay, gravel and river pebbles of similar size (Fig. 4).

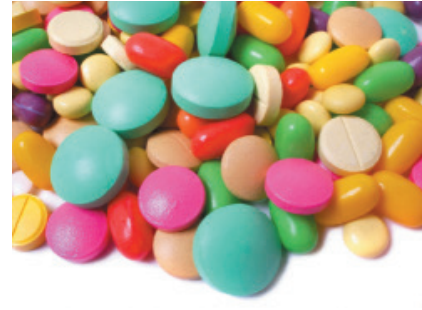

Pills

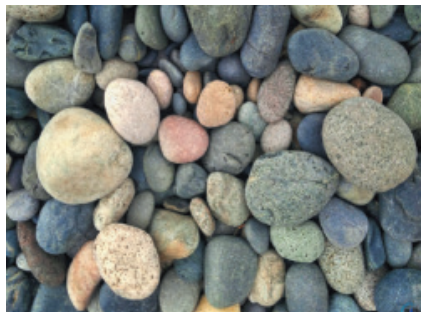

Stones
Fig. 4. General view of the tablets and stones introduced into the model of the stomach cavity

4. ábra A gyomorüreg modelljében felhasznált tabletták és kavicsok általános képe

\section{Results and discussion}

It is shown that all the tablets, food and water go down to the bottom of artificial gastric reservoir and move inside its cavity because of gravity, as well as river sand, pieces of chalk, clay, gravel and pebbles. We found that corrected specific gravity of all modern tablets is greater than $1 \mathrm{~g} / \mathrm{cm}^{3}$ and therefore all the tablets sink in gastric juice, water and milk. We also found that if the container is placed vertically, all the tablets fall in one place, and then lie still in the bottom of the cavity like river pebbles in a glass of water, despite of the liquid being added (Fig. 5).
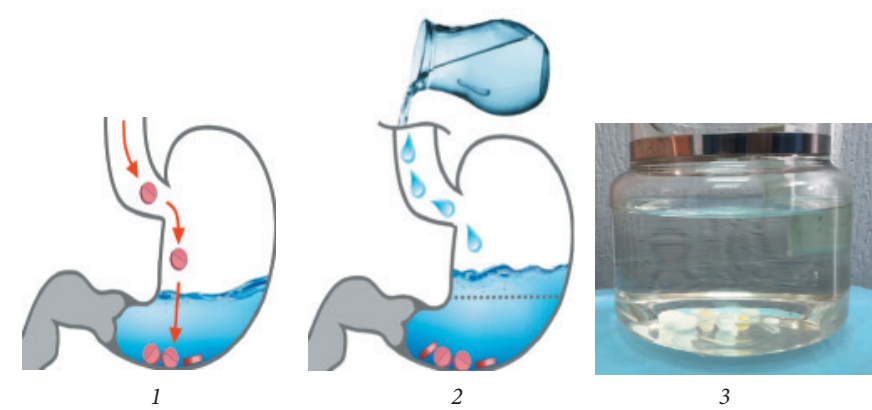

Fig. 5. Influence of gravity and water on placement in the stomach cavity tablets (1 and 2) and stones (3)

5. ábra A gravitáció és a víz hatása tabletták (1 és 2) valamint kavicsok (3) elhelyezkedésére a gyomorüregben 
However, unlike the pebbles and crushed stones, tablets have aggressive impact on gastric mucosa, they corrode the stomach wall, and may lead to ulcers. The tablets that are most blamed for causing ulcers in the stomach wall are aspirin and its analogs which are known as non-steroidal anti-inflammatory agents. Our results indicate that in the medication name present wickedness.

We were the first to see the truth about physiological form of modern tablets. With our theoretical, laboratory and clinical research, we were able to get rid of this pharmaceutical delusion. Today we are sure that manufacturing tablets in a circular disk form is a mistake. This form of tablets is not compatible with the specifics of human digestive system.

Disk form of tablets is useful only for manufacturers and sellers. However, we do not have standard even for this form of tablets. Surprisingly, today there is no standard not only for the form of tablets, but also for their sizes. Therefore, different manufacturers produce tablets in different forms and size.

Our results show that modern tablets differ in diameter and height by up to 3 times, and by up to 10 times in volume.

We decided to analyze the shape and size of the object, which people usually swallow after thorough chewing of food in their mouth. In science, this object is known as food bolus. For this purpose, we studied the shapes and sizes of food lumps formed in the oral cavity in adult healthy people when chewing fresh bread. We found that natural bolus has a form of an olive with its largest diameter up to $1 \mathrm{~cm}$, and maximum length of $2 \mathrm{~cm}$ [14]. This olive is dark, has close to zero hardness and medium elasticity, it is porous and has a specific gravity of less than $1 \mathrm{~g} /$ $\mathrm{cm}^{3}$, besides, it lacks osmotic aggressiveness towards contents of the mouth and stomach (Fig. 6)

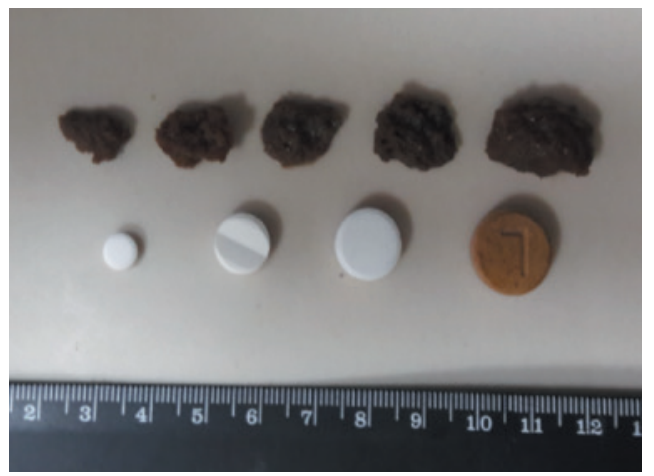

Fig. 6. Range value of diameter and volume of tablets and food bolus 6. ábra Átmérö és térfogat terjedelme tabletták és összerágott étel esetén

Man is capable to swallow soft and elastic olives, but not hard disks [15]. Besides, we found that there is no standard for tablets chewing resistance and disintegration in gastric juice, so they are manufactured with varying chewing resistance and disintegration characteristics. All this increases the range of nonspecific physical-chemical effects of tablets inside the mouth and stomach.

In particular, our results showed that modern tablets differ in chewing resistance by up to 5000 times (Fig. 7).

So today, no one knows the true hardness of each tablet. Therefore, today no one knows what will crumble first while chewing, a tablet or a tooth.

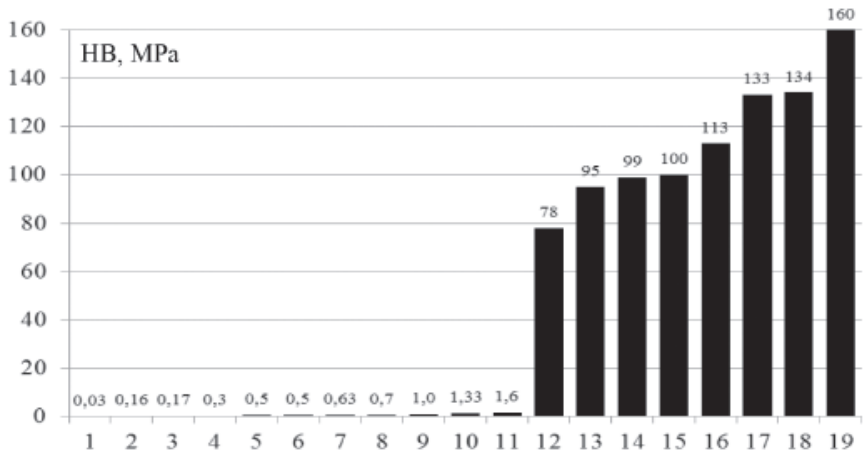

Fig. 7. Hardness of 19 tablets of various drugs

7. ábra 19 különbözö gyógyszertabletta keménysége

The results of our experiments showed that under the simulated conditions, the mixture of oatmeal porridge, gastric juice, and water had the following physical-chemical characteristics:

- Viscosity - in the range of 200 - 500 centipoise,

- Acidity - in the range of $\mathrm{pH} 4.5$ - 8.0,

- Osmolarity - in the range of 240 - $340 \mathrm{mOsmol} / \mathrm{l}$ of water.

Then, we introduced into the mixture 20 small river pebbles in the form of circular disks with the diameter of about 6-20 $\mathrm{mm}$, height of 2-6 $\mathrm{mm}$ and volume of $0.1-1.0 \mathrm{~cm}^{3}$, and during one hour after that the physicochemical properties of the contents remained virtually unchanged.

Different results were obtained after we introduced 20 tablets of similar shapes and sizes into a similar mixture of cereal, water and gastric juice. In 30 minutes after putting them in this mixture, the contents had the following physicochemical characteristics:

- Viscosity - 100 - 300 centipoise;

- $\quad$ Acidity - pH 6.0 - 7.1;

- Osmolarity - 240 - $340 \mathrm{mOsmol} / \mathrm{l}$ of water.

In 30 minutes after adding 20 tablets to the empty plastic container (modelling taking tablets in the fasting state), tablets disintegrated halfway. The container contents appeared as suspension with non-decomposed pieces of tablets and had the following physicochemical properties:

- Viscosity value 0 - 10 centipoise;

- Acidity - pH 2.0 - 3.3;

- Osmolarity - 340 - $600 \mathrm{mOsmol} / \mathrm{l}$ of water.

Thus, pharmaceutical companies manufacture tablet-form medications with physical or physical-chemical properties, which are entirely different from those of natural food bolus, which we have in our mouth before swallowing. It was shown that conventional shape, color, size, volume, specific gravity, hardness, osmotic and acidic properties of tablets affect the physical and physical-chemical properties of oral and gastric cavities contents. It is proved that improper physical and physical-chemical characteristics of modern tablets result in reduced medication safety for the digestive system, and increase their non-specific physical and physical-chemical aggressiveness when ingesting.

\section{Conclusions}

The human digestive system happily accept pills only if their physical and physicochemical properties will not differ 
corresponding properties of natural food lumps produced in the oral cavity of the quality of food.

\section{References}

[1] Urakov, A. L. et al. (2007): Newton's Binomial as a "formula" development of medical pharmacology. Institute of Applied Mechanics Ural branch of the Russian Academy of Sciences, Izhevsk, 192 p.

[2] Urakov, A. L. - Reshetnikov, A. P.: Specific deforming the hardness of the tablets is another indicator of the quality of medicines. (2014) Success of Modern Natural Science, no. 9 (2), pp. 33 - 37

[3] Urakov, A.L. - Urakova, N.A. - Reshetnikov, A.P., et al.: Enterokolit, gastrit, stomatit, gingivit i karies vyzyvayut tabletki atsetilsalitsilovoi kisloty. (2008). Med. Almanac, no. 2, pp. $45-48$

[4] Urakov, A. L. - Strelkov, N. S. - Lipanov, A. M. - Dementiev, V. B. Urakova, N. A. et al.: Physical-chemical and hydrodynamical ways of increasing safety of intestine.(2007) Chemical Physics and Mesoscopics, no. 9 (3), pp. 231-238

[5] Urakova N. A. et al.: Floating tablet. (2005) Invention RU Patent 2254121 C2

[6] Urakov, A. L.: The change of physical-chemical factors of the local interaction with the human body as the basis for the creation of materials with new properties. (2015) Épitöanyag - Journal of Silicate Based and Composite Materials, no 67 (1), pp. 2 - 6

[7] Korovyakov, A. P., et al.: Individual'nye osobennosti upravleniya protsessom fizicheskogo peremeshcheniya tverdykh i zhidkikh lekarstvennykh form vnutri zheludka. (2003) Eksperimental'naya $i$ klinicheskaya gastroenterologiya, no. 1, pp. 30 - 32

[8] Strelkov, N. S., et al.: Clinical features of passive intragastric pharmacokinetic binding, enveloping, absorbent and antacid drugs (2002). Morphological newsletter, no. 3, pp. 95-96.

[9] Urakov, A. L. - Strelkov, N. S. - Urakova, N. A. et al.: Ultrasound as a method of study travel medical imaging solid forms in the stomach.(2008). Eksperimentalnaia i klinicheskaia gastroenterologiya, no. 2, pp.27-29

[10] Urakov, A. L. - Urakova, N. A.: Using aftheregularitiesof the gravitational intracavitary pharmacokinetics of drugs for controlling the process of their distibution inside the cavities by means of changing the position of the patients. (2006). Biomeditcina, no. 4, pp. 66-67.

[11] Urakov, A. L. - Urakova, N. A. - Mihailova, N. A. - Reshetnikov, A P.: Nonspecific properties of tablets, affecting the transport and action of drugs in the oral cavity, stomach, and intestine. (2007). Meditsinskaia pomoshc, no. 5 , pp. $49-52$
[12] Urakov, A. L. (2014): Development of new materials and structures based on managed physico-chemical factors of local interaction. In L. A. Gömze (Editor) 3rd International Conference on Competitive Materials and Technology Processes, Miskolc-Lillafüred, Hungary, pp.9.

[13] Urakov A. L. - Urakova N. A. - Kozlova T. S.: Local toxicity of drugs as an indicator of the likely aggressiveness of the local application. (2011) Bullitin of Ural Academy Medical Sciences, no. 1 (33), pp. 105 - 108

[14] Urakov, A., et al.: Artificial food bolus and method forinstant assessment of dento-facial health with using artificial food bolus.(2014) Invention $R U$ Patent 2533840 C2

[15] Nikitiuk D. B. - Reshetnikov A. P. - Nasirov M. R.: How to protect the human digestive system from the aggressive action of tableted drugs.(2016). Modern problems of science and education. no. 2. URL: http://science-education.ru/ru/article/view?id=24185 (date of the application: 22.10 .2016$)$

\section{Ref.:}

Urakov, Aleksandr - Urakova, Natalia - Reshetnikov, Alexey Kasatkin, Anton - Kopylov, Maxim - Baimurzin, Dmitry: About what is happening in the stomach after swallowing human river pebbles, gravel, chalk, clay and tablets drugs Épitőanyag - Journal of Silicate Based and Composite Materials, Vol. 68, No. 3 (2016), 110-x113. p http://dx.doi.org/10.14382/epitoanyag-jsbcm.2016.19

Mi történik a gyomorban folyami kavics, mészkő, agyag és gyógyszer tabletták lenyelését követően Megfigyelhetô, hogy a gyógyszergyártó cégek a gyógyszereket olyan tabletták formájában gyártják, amelyek fizikai és fizikokémiai jellemzôikben nagymértékben eltérnek a természetes ételtôl, amelyet a páciens megrág a lenyelést megelôzően. Kimutatható, hogy a hagyományos alakú, méretú, térfogatú, sưrūségú, keménységú, ozmotikus aktivitású, kémhatású modern tabletták negatív irányban változtatják a gyomornedv fizikai és fiziko-kémiai tulajdonságait. Ezek a változások erôteljesebbek annál, mintha építôanyag (mészkô, agyag, homok, folyami kavics) kerülne a gyomorba.

Kulcsszavak: ember, tabletta, gyógyszer, agyag, mészkô, kavics, fiziko-kémiai jellemzốk
International Concrete Conference \& Exhibition
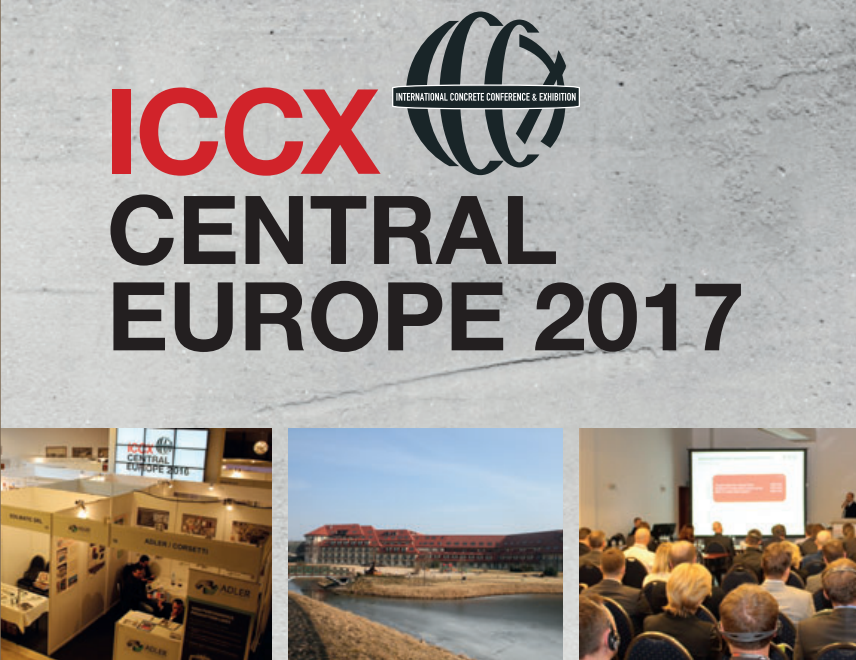

www.iccx.org
The preparations for the ICCX Central Europe 2017 are almost complete and the participants can look forward once again to a highly interesting and extensive offering, which the organisers of the ICCX Central Europe have put together.

A high-class, two-day conference programme is on the agenda, rounded off by the exhibition to accompany the conference with over 100 booths. Further highlights of the ICCX Central Europe 2017 are the Concrete Block Centre and the workshops to be held by some of the exhibiting companies. With a half-day technical course on the day following the conference, an additional offering has been created that hadn't existed at this year's ICCX Central Europe.

The venue for the next ICCX Central Europe, which will take place on $\mathbf{8}$ and 9 February 2017, will once again be the Hotel Ossa Congress \& Spa, situated to the south of Warsaw. A shuttle service will once again enable an uncomplicated transfer from the airport to the Congress Hotel and, of course, back again.

https://iccx.org/central-europe/event-details-en 